\title{
Understanding the multiculturalism values through social media among Indonesian youths
}

\section{Pemahaman nilai-nilai multikulturalisme melalui media sosial di kalangan pemuda Indonesia}

\author{
Tuti Budirahayu, Marhaeni M. Wijayanti, \& Katon Baskoro \\ Department of Sociology, Faculty of Social and Political Sciences, Universitas Airlangga \\ Address: Dharmawangsa Dalam, Surabaya, East Java 60286 \\ E-mail: tuti.budirahayu@fisip.unair.ac.id
}

\begin{abstract}
The diversity of Indonesian people can be a problem when they do not have a sense of brotherhood based on the diversity of religion, culture, language and ethnic groups. Understanding diversity is known by young people through various media outlets. This study aims to understand the level of the knowledge of youths concerning the values of pluralism and multiculturalism. This study also intends to find out whether social media influence the knowledge and their understanding of pluralism and multiculturalism. However, the demographic bonus could be a burden for the countries involved, particularly when the generation lacks competitiveness. This can even cause the disintegration of this nation. This study was a quantitative research study conducted using the survey method. The respondents consisted of 400 young people in high school or the equivalent. The study was conducted in three cities in East Java, namely Surabaya, Pasuruan, and Kediri. The samples were taken using the multi-stage cluster random sampling method. The data was obtained through structured questionnaires and processed using SPPS for Windows 16. The results can be explained as follows; even though more than fifty percent of the youths in this study claimed to have never heard or known of the term "pluralism" and "multiculturalism", their level of comprehension of pluralism and multiculturalism values was good enough. This was influenced by the information that they got through social media. The values that are understood more by the youths through social media in this study tend to be more orientated to pluralism values than multiculturalism. The most understood pluralism values are plurality and diversity. This is in line with their assessment of the role and quality of the information available on social media, which tends to contain pluralism values rather than multiculturalism values.
\end{abstract}

Keywords: multiculturalism; social media; diversity

\begin{abstract}
Abstrak
Keragaman masyarakat Indonesia bisa menjadi masalah ketika mereka tidak memiliki rasa persaudaraan berdasarkan keragaman agama, budaya, bahasa dan kelompok etnis. Memahami keragaman dikenal oleh orang-orang muda melalui berbagai media. Penelitian ini bertujuan untuk memahami tingkat pengetahuan remaja tentang nilai-nilai pluralisme dan multikulturalisme. Penelitian ini juga bermaksud untuk mengetahui apakah media sosial mempengaruhi pengetahuan dan pemahaman mereka tentang pluralisme dan multikulturalisme. Penelitian ini merupakan penelitian kuantitatifyang dilakukan menggunakan metode survei. Responden terdiri dari 400 anak muda di sekolah menengah atas atau yang setara. Penelitian dilakukan di tiga kota di Jawa Timur, yaitu Surabaya, Pasuruan, dan Kediri. Sampel diambil menggunakan metode multistage cluster random sampling. Data diperoleh melalui kuesioner terstruktur dan diproses menggunakan SPPS untuk Windows 16. Hasilnya dapat dijelaskan sebagai berikut; Meskipun lebih dari lima puluh persen pemuda dalam penelitian ini mengaku belum pernah mendengar atau mengetahui istilah "pluralisme" dan "multikulturalisme", tingkat pemahaman mereka tentang pluralisme dan nilai-nilai multikulturalisme cukup baik. Ini dipengaruhi oleh informasi yang mereka dapatkan melalui media sosial. Nilai-nilai yang dipahami lebih oleh pemuda melalui media sosial dalam penelitian ini cenderung lebih berorientasi pada nilai-nilai pluralisme daripada multikulturalisme. Nilai pluralisme yang paling dipahami adalah kemajemukan dan keragaman. Hal ini sejalan dengan penilaian mereka tentang peran dan kualitas informasi yang tersedia di media sosial, yang cenderung mengandung nilai-nilai pluralisme daripada nilai-nilai multikulturalisme.
\end{abstract}

Kata kunci: multikulturalisme; media sosial; keragaman 


\section{Introduction}

The spread of radicalism in Indonesia, marked by acts of terror by certain religious groups, is of particular concern for the nation. The bomb explosions by the terrorists that occurred in the middle of 2018 were the most recent regarding the aggressiveness of the radical movement. These radical actions are not only done by adults but also by youths, and even women, and children. The study of the involvement of youths in the acts of radicalism in Indonesia (Muhammad \& Pribadi 2013) show that various factors such as poverty, injustice and improper education about religious understanding within the families and schools, and the expanding network of radical groups, can affect the youths who are experiencing an identity crisis.

The involvement of the youths in radical groups, apart from being caused by the above factors, can also be triggered by information disclosure. In Indonesia, this started after the collapse of the New Order regime in 1998 to the present. In the reform era, the Indonesian people obtained the space for freedom of expression through various forms of media, including social media. The space for freedom can, in a sense, strengthen the identity of the social and sub-cultural groups that were once repressed by the New Order regime. This article does not explain about the radicalism among the youths or the emergence of identity groups that lead to radical movements in Indonesia. This study intends to derive how the Indonesian youths, especially in East Java, understand the values of pluralism and multiculturalism as the antithesis of the radicalism that has been distributed through various information on social media. The potential for radicalism can be suppressed through the peaceful values and tolerant attitudes towards differences and diversity (Nurudin 2013). The phenomenon of radicalism that emerged in the reform era hypothetically can be the cause of the Unitary State and Indonesia's collapse. Indonesia, which is actually plural and multicultural, still has to be wary of any ideology that can destroy the unity of the nation. Thus, we must be concerned of radical and separatist ideologies because they are anti-pluralism and anti-multiculturalism.

The concepts of pluralism and multiculturalism bear a resemblance to one another, because both of them accept the diversity of groups in society. Specifically, they have different emphases. Pluralism is the understanding that people of various races, religions, cultures, languages or political ideologies can live peacefully in the same society. The emphasis on pluralism is more on the effort to live peacefully in the midst of their differences. Multiculturalism has a deeper understanding, because it means not only living peacefully in diversity, but being able and willing to respect, accept, and recognize the differences that exist in society. Multiculturalism is an idea that states that society must consist of many different cultural groups with the same social status, or that it should at least allow different cultural groups to live in one area. Multiculturalism can also be understood as a world view which is then manifested in the "politics of recognition" (Azra 2007). The meaning of the statement is that multiculturalism respects the variety of life in the world, or the cultural policies that emphasize the acceptance of the existence of cultural or ethnic (multicultural) diversity that exists in people's lives, concerning the values, systems, culture, habits and politics that they hold. There should also be aspirations to develop the same national spirit and to have pride in maintaining that plurality.

An understanding of pluralism and multiculturalism can be obtained from various sources, including social media. Social media, if it used properly, can become a learning medium or an agent of socialization, including the values of pluralism and multiculturalism (Parikesit 2013). Therefore, the focus of this study was the social media used by the youths of Indonesia and it refers to the data from the Ministry of Communication and Information of the Republic of Indonesia (Kominfo RI) in 2017. The data shows that the use of social media among youths is quite massive, at around 75.5 percent. The largest penetration of internet users was at the ages of 13 to 18 years old (Kominfo 2018).

The focus of this study is the assessment of the youth's concerning the information available on social media, especially that which contains the values of pluralism and multiculturalism. This study also wants to determine whether social media influences their knowledge and understanding of pluralism and multiculturalism. The space for the freedom of information experienced by the youths 
in the millennial era has its own consequences on their understanding of nationality and pride in the homeland that has diversity in its cultures, ethnicities, religions, and languages. In more detail, the purpose of this study can be explained in five points. The first is understanding the knowledge level of the youths concerning the values of pluralism and multiculturalism. Second, is the youth's assessment of the role of social media as an agent for socializing pluralism.

Third, is their level of trust in the varied information on social media that supports pluralism and multiculturalism values. Fourth, is the correlation between the role of social media as an agent for socializing the values of pluralism and multiculturalism and the youth's level of understanding of those values. The last is the correlation between the quality of information that supports the values of pluralism and multiculturalism on social media, and the youth's level of understanding toward pluralism and multiculturalism.

The Indonesian youth's understanding of pluralism and multiculturalism may not be as good as their understanding of "Bhinneka Tunggal Ika" (a Sanskrit sentence that means "Though divorced but still one"). Bhinneka Tunggal Ika is a slogan written on the Indonesian emblem; it means that even though the Indonesian nation consists of various ethnicities, cultures, religions, and languages (multi-ethnic-multicultural), it remains integrated as a unitary state. The term "Bhinneka Tunggal Ika" has been taught to Indonesian youths since elementary school, through to college via the Pancasila and Citizenship (PPKN) subject. The lessons have been held since the 1960s, during the President Soekarno leadership era. The purpose of these lessons is to instill national values and character building (unity) because the Indonesian nation is vulnerable to conflict due to the diversity of its ethnics, religion, culture, and language (Maftuh 2008).Therefore, PPKN as the subject is legally accepted by the Indonesian Constitution and National Education System because of its education on multiculturalism. It becomes one of the subjects that must be taught by teachers at all levels of education (Winataputra \& Saripudin 2008).

On another hand, although PPKN details the value of pluralism and multiculturalism in its study, the implementation at the empirical level is still not as ideal as aspired to by President Soekarno. The data collected from the Fellowship of Indonesian Brothers in America (FICA), the Indonesian Church Fellowship (PGI), the Kompas Information Center (PIK), and the Tempo Data and Analysis Center (PDAT) showed that the cases of church destruction and forcible closure by the community and security forces has increased each year. The peak of these cases occurred during the leadership transition from the Soeharto Order to the Reform Order (Misrawi 2012). The intolerance phenomenon has also continued to occur in various regions in Indonesia, including violations of freedom of religion or belief. The report of The Wahid Institute in 2008 showed that there has been opposition to religious pluralism, which includes: (1) the misdirection of groups or individuals, (2) religious-based violence, (3) regulations with religious nuances, (4) conflict in places of worship and (5) the issue of spreading hatred towards the adherents of other religions. The occurrence of anomalies in the values of multiculturalism show that national values and diversity still have to be internalized continuously, especially by youths as the nation's next generation.

The efforts to instill national values in the lives of youths not only can be done through school subjects, but it can also be developed through various forms of media, both mass media (offline) and internet-based social media (online). This is due to the social functions of mass media, both offline and online. The first function is providing information about various events in the community. Second, is educating the public to be able to think and broaden their knowledge. Third, is evoking a sense of empathy that is able to generate projective abilities. Fourth, is strengthening the integration of groups, communities and nations. Fifth, is preserving and bequeathing cultural values from one generation to the next. Sixth, is increasing political activity and ideology (Sutaryo 2007).

Through social media, youths can communicate and exchange information, including that which is related to education and entertainment. The study conducted by Ayun (2015) showed that youths use social media, in general, to communicate and connect with other people. Through communication, they have a personal orientation, such as wanting to express themselves and indirectly showing their 
identity. Social media networks are able to produce and reproduce various items of information. Manuel Castells explained, in his theory of network society (Sugihartati 2014), that the interactions that occur between community members in the millennial era can be formed quickly through a network. Furthermore, according to Castell, the revolution of information that began in America in the 1970's not only caused social changes in the field of information management, but also it eventually gave birth to informational capitalism. Through informational capitalism, the main source of production no longer relies on capital strength, but more on the use and optimization of knowledge information. Thus, information plays an important role in the social, economic and political activities within society. The use of knowledge and information also eventually affects social order. In addition, in this era of information, the presence of cyber-activities and networks allows communication flows to run in any direction and to any level of a structure without the interference from other parties.

The above explanation about what knowledge and information can do prompts the question, "Is the information and knowledge about the values of pluralism and multiculturalism effectively understood and internalized by youths through social media networks?" To answer this question, we must understand beforehand the perspectives of thought from the cultural study experts on media and the use of media among youths. Barker (2000) quotes the thoughts of Chambers and Hebdige, stating that media users (in this case, television viewers) have creative potential, forming the basis for the construction of diverse and meaning-oriented identities. Barker (2000), quoting Fiske's thinking, stated that pop culture (in this case, social media) is constructed by the meanings that are created by individuals rather than as something that can be identified in the text. In addition, social media, which is also a part of youth culture, tends to be used as a medium to gain pleasure and social identity. Barker (2000) also cites Paul Willis's thinking, stating that the information obtained by the youths through various media is a process of the general commodification of culture. It is the creation of meaning by all people as the producers of culture. Thus, youths are adept at reading images and they are able to play with interpretations and codes.

According to the statements from the cultural experts, it can be said that the youths of Indonesia obtain the values of pluralism and multiculturalism through social media. On the other hand, their interpretation of the information from social media that contains the values of multiculturalism may not be textual, as they learn from the school's textbooks as well. The information about the multiculturalism values that they get and share with others through social media may have been processed in such a way that it results in an already reproduced chunk of information with more creative forms in accordance with the culture of the youths who tend to seek pleasure and entertainment, and everything that represents their identity.

\section{Research Method}

The study was conducted in three cities in East Java, namely Surabaya, Pasuruan, and Kediri. The choice of the research location was based on the consideration of the people's condition in each city, focusing on the level of heterogeneity (for Surabaya and Kediri) and the homogeneity of the community (for Pasuruan City). The schools selected as the samples were also based on variations in the school categories, which consisted of 1) public schools, 2) private schools with a religious background (taken into account the number of religions in each city; Islam, Christianity, and Catholicism) and 3) Islamic boarding schools, which are a type of Islamic education institution.

The population of this study consisted of high school students who were in the first to third grade. The samples were taken using the multi-stage cluster random sampling method. The sampling stages were as follows. First, we grouped the schools in each city based on variations in the school categories. Second, we randomly selected the schools that were going to be the sample based on the population of the category frequency in each city. Third, after obtaining the types of school for each city, we randomly selected a number of students from each school.

Through this sampling method, four types of schools were selected in Surabaya (public schools, private schools with an Islamic background, private schools with a Christian background, and Islamic 
boarding schools). From each type of school, we took a sample of 200 students. In Kediri, two types of schools were taken (Catholic private schools and Islamic boarding schools) with a total sample of 100 students. In Pasuruan, two types of schools were taken (Islamic self-help schools and Islamic boarding schools) with a total sample of 100 students. The total sample of this study as a whole was 400 students. The method of the data collection was done by distributing structured questionnaires to the respondents in each school and asking them to fill them in. The data was processed using SPPS for Windows 16.

The data was analyzed using frequency tables for the single variables. The test of the variable correlation was carried out using Kendal's Tau correlation test statistics, with a 99 percent confidence level.

\section{Results and Discussion}

\section{The characteristics of the youths}

The age range of the youths who were respondents in this study ranged from 16 to 18 years old, and the highest frequency for the age range was between 16 and 17 years (76.5 percent). Most of them were still in second-grade at high school. The religion of the respondents was quite varied, but most of them were Muslim (74 percent). The other respondents' religions included Christian (18 percent), Catholic (6 percent), Hindu (4 percent), Buddhist ( 0.5 percent) and Confucian ( 0.3 percent). Since this research study was conducted in East Java, most of the respondents were Javanese (81 percent), while the others came from particular tribes like Madura (7.5 percent), Sundan ( 0.3 percent), Batak (2.3 percent), Minang ( 0.8 percent) and Betawi ( 0.3 percent).

The occupation of the respondents' fathers was quite varied; Civil Servants (10.5 percent), private employees ( 32.5 percent) and entrepreneurs ( 40 percent). While the mothers were mostly housewives (58 percent), some of them worked in the formal and informal sectors, such as in the role of a Civil Servant (6 percent), private employee (13 percent) and self-employed individual ( 23 percent). The socio-economic status of the respondent's family can be seen from the parents' level of education and income. The education level of the majority of the respondents' fathers was that of middle school ( 80 percent), while the majority of the respondents' mothers were at the middle or the lowest level of education (66 percent). The average income level of the parents of the respondents per month tended to be above the average regional minimum wage in East Java, which ranged from Rp 3.000.000 to Rp 7.000.000 (55 percent). The average income level of the parents of the respondents per month tended to be above the average regional minimum wage in East Java, which ranged from $\mathrm{Rp} 3.000 .000$ to $\mathrm{Rp} 7.000 .000$ (55 percent). By paying attention to the level of education and the income of the respondents' parents, it can be said that the youths who made up the sample of this study generally came from middle-class families.

Regarding the use of social media among the youths, the data shows that as many as 97 percents are active users of social media platforms or online media. The types of social media that are most frequently accessed are WhatsApp (88 percent), Instagram (81 percent), Youtube (78 percent) and Line (64 percent). Twitter and Facebook seem to have been abandoned because only 21 percent of the respondents were Twitter users, and 56 percent still use Facebook. Furthermore, the shift in the use of social media types among youths is very fast. The study conducted by Abadi, Sukmawan, \& Utari (2013) around five years ago showed that the most frequently accessed social media platforms were Facebook and Twitter, followed by Line, We Chat, and WhatsApp. According to Bohang (2016), the cause of the shift in the use of social media is the preference of the youths. Nowadays, they prefer social media platforms with visual content and less text. In addition, these types of social media do not discuss many political issues, including political campaigns, or writings that require serious thinking.

\section{The understanding of youths of pluralism and multiculturalism}

Based on these understandings, the statements used in this study to describe the values of pluralism 
were 1) respecting the differences in habits and traditions, 2) positively regarding the plurality of groups, religion, culture, ethnicity, and language (KABSA), 3) avoiding disputes due to differences in KABSA, 4) giving a space for people with different KABSA and 5) accepting the presence of people with different KABSA.

Multiculturalism, meanwhile, uses different statements to describe its values: 1) recognizing the diversity of KABSA, 2) recognizing the rights and identities of minority groups, 3) recognizing equality between KABSA, 4) accepting the traditions of various sub-cultures and preserving diversity and 5) developing nationalism based on pluralism.

Pluralism and multiculturalism are actually well-known among Indonesian youths through the term "Bhinneka Tunggal Ika". On the contrary, the "pluralism" and "multiculturalism" terms are possibly still unfamiliar for some Indonesians. The result of this study proved that only 41 percents of respondents know or have heard about the term pluralism and multiculturalism, while 59 percents of the respondents claimed that they had never heard about it. This result means that more than half of the respondents do not know of the "pluralism" and "multiculturalism" terms in their daily lives, although these terms almost have a similar meaning to "Bhinneka Tunggal Ika", which they learned in elementary school. On the other hand, although the term or concept of pluralism and multiculturalism was not recognized by more than half of the respondents, the elaboration of its values is better understood by the youths who are the respondents in this study. In this study, the elaboration of both values is based on the understanding that pluralism is a plurality and that the difference is accepted as a reality (Rahman 2014). Meanwhile, multiculturalism is an understanding that recognizes and glorifies the differences in alignment, both individually and culturally (Suparlan 2014). In short, although the concept of pluralism and multiculturalism both describe socio-cultural diversity, the understanding of both is somewhat different (Syaifuddin 2006). Pluralism is at the level of pluralistic understanding or the perspective that emphasizes the different entities in society; it does not pay attention to the interactions between different groups of society. While multiculturalism is an understanding and perspective that emphasizes the interactions between the different groups, they do still have equal rights.

Regarding the above explanation, the Likert scale was used to measure the level of understanding of the youths concerning the values of pluralism and multiculturalism. The Likert scale was used to analyze the tendency of people to agree or disagree with the statements and in this study, the statement was about understanding the practices of people's lives that reflect the values of pluralism and multiculturalism. To analyze the level of the respondents approval of this statement, this can be determined from the largest percentage of the respondents' answers and whether they show agreement or an understanding of the values of pluralism and multiculturalism. Table 1 is data on the respondents.

Based on the data distribution in the Table 1 and Table 2, there are four points that can be seen. First, the youth actually understand pluralism and multiculturalism. Second, they are understood accepting people of different ethnicities, religions, languages, and cultures (46.8 percent). Meanwhile, the value of pluralism which is most sufficiently understood is how the youths regard plurality positively (60 percent). Third, the multiculturalism value that the youths understood very well was the acknowledgment of diversity ( 35.3 percent), while the value that they sufficiently understood was the acceptance of various sub-cultures and traditions (60.5 percent). The values of pluralism that were not understood by the respondents included the value of the willingness to give a place or space to those of a different ethnicity, religion, language, and culture, while the most incomprehensible values of multiculturalism were the acknowledgment of the rights and identity of the minority groups (16 percent).

From the respondents' answers about their knowledge and understanding of the pluralism and multiculturalism concepts and values, there are several things that can be considered as important findings in this study. First, although more than half of the respondents answered that they did not know the meaning of the terms pluralism and multiculturalism, there was quite a lot who understood its values. In comparison, however, pluralism values are more understandable than multiculturalism 
values. The second finding is that the values most understood by the respondents are the willingness to accept pluralism and differences, as well as the acknowledgment of diversity. This means that the concept of pluralism and diversity is better known compared to multiculturalism values. Multiculturalism values that cannot be understood include the acknowledgment of those who are different, and the acknowledgment of the rights and identities of minority groups.

Table 1.

The Understanding Level of Pluralism Values

\begin{tabular}{lccc}
\hline \multicolumn{1}{c}{ Values } & $\begin{array}{c}\text { Excellently } \\
\text { understand }\end{array}$ & $\begin{array}{c}\text { Sufficiently } \\
\text { understand }\end{array}$ & $\begin{array}{c}\text { Do not } \\
\text { understand }\end{array}$ \\
\hline Respect the diversity & $43,3 \%$ & $52,8 \%$ & $4 \%$ \\
Positively regard plurality & $33,2 \%$ & $60 \%$ & $6,8 \%$ \\
Avoid any disputes & $39,8 \%$ & $54,8 \%$ & $6,4 \%$ \\
Give space for the differences & $37,5 \%$ & $54,5 \%$ & $8 \%$ \\
Willing to accept diversity & $46,8 \%$ & $48,2 \%$ & $5 \%$ \\
\hline \multicolumn{4}{c}{ Source: Analyzed from the primary data }
\end{tabular}

According to the findings of this study, it can be said that multiculturalism among the youth of Indonesia tends to be poorly understood. This is due to the notion or concept of multiculturalism, which is more complex compared to pluralism. The findings of this study are in line with the study conducted by Parsley (2000) in three countries (Singapore, Australia, and the United States of America). Multiculturalism in these countries is actually a complex matter because it becomes a growing social reality. This issue is a condition that continues to be debated politically, yet it is pursued in various policies and continuously internalized through educational institutions. Therefore, understanding multiculturalism is not as simple as understanding pluralism, which tends to only explain at the level of diversity. Logli (2015) also conducted a study on the understanding of the concept of Bhinneka Tunggal Ika, which was taught at the tertiary education level in Indonesia. Logli concluded that almost all students who learned about Bhinneka Tunggal Ika through the Pancasila Moral Education subject tended to comprehend it as an internalization process about the spirit of unity and diversity. They did not see it as a part of the multicultural education that teaches them the interaction between ethnic div ersity, religion, and language.

Table 2.

The Understanding Level of Multiculturalism Values

\begin{tabular}{lccc}
\hline \multicolumn{1}{c}{ Values } & $\begin{array}{c}\text { Excellently } \\
\text { understand }\end{array}$ & $\begin{array}{c}\text { Sufficiently } \\
\text { understand }\end{array}$ & $\begin{array}{c}\text { Do not } \\
\text { understand }\end{array}$ \\
\hline Acknowledge diversity & $35,3 \%$ & $57,1 \%$ & $7,6 \%$ \\
Acknowledge minority groups & $23,8 \%$ & $60,2 \%$ & $16 \%$ \\
Acknowledge equality & $32 \%$ & $58,8 \%$ & $9,2 \%$ \\
$\begin{array}{l}\text { Accept the variety of sub-cultures } \\
\text { and traditions }\end{array}$ & $34 \%$ & $60,5 \%$ & $5,5 \%$ \\
$\begin{array}{l}\text { Develop the spirit of nationalism } \\
\text { based on pluralism }\end{array}$ & $32,8 \%$ & $59,4 \%$ & $7,8 \%$ \\
\hline
\end{tabular}

Source: Analyzed from the primary data

\section{The role of social media as an agent for socializing the values of pluralism and multiculturalism}

Social media plays a role in influencing the attitudes, thoughts, knowledge and understanding of youths about the values of pluralism and multiculturalism. This is because nowadays, they do not only learn from their family, friends and school. Thus, it is important to study the assessment of the youths toward the information that they access through social media, particularly information that contains pluralism and multiculturalism values. The types of information often accessed on social 
media by the youths in this study included music (74 percent), films (71.8 percent), social activities, artists ( 58 percent), entertainment ( 58 percent), religion ( 51 percent ) and education (50 percent). The information that is rarely accessed includes politics (44.3 percent), law (39 percent), economy (38 percent), sports ( 25 percent) and crime ( 25 percent).

The data shows that social media is often accessed by youths for them to get access to various types of information such as entertainment in the form of movies, music, the latest news about their idols or artists, religion, and education. On the contrary, the information that is rarely accessed is about politics, law, and economics. This means that they tend not to be interested in information that is considered heavy or difficult to understand. Even though the information accessed can be considered light topics, according to them, there are values of pluralism and multiculturalism contained in the information that they access. The following is the data about the youth's perceptions of social media role as an agent of socializing the values of pluralism and multiculturalism.

Table 3.

The Role of Social Media in Socializing Pluralism Values

\begin{tabular}{lccc}
\hline \multicolumn{1}{c}{ Values } & Never & Occasionally & Often \\
\hline Respect diversity & $8,2 \%$ & $22,8 \%$ & $69 \%$ \\
Positively regard plurality & $11,2 \%$ & $17,8 \%$ & $71 \%$ \\
Avoid any disputes & $10,2 \%$ & $26,3 \%$ & $63,5 \%$ \\
Give space for the differences & $14,2 \%$ & $19,5 \%$ & $66,3 \%$ \\
Willing to accept diversity & $8 \%$ & $15,5 \%$ & $76,5 \%$ \\
\hline
\end{tabular}

Source: Analyzed from the primary data

The data distribution in Table 3 and Table 4 shows that the respondents often found information that contained pluralism and multiculturalism values. The pluralism values often found in social media were about the willingness to accept and respect differences (69 percent), as well as the acceptance of pluralism (71 percent).

Table 4.

The Role of Social Media in Socializing Multiculturalism Values

\begin{tabular}{lccc}
\hline \multicolumn{1}{c}{ Values } & Never & Occasionally & Often \\
\hline Acknowledge diversity & $8,1 \%$ & $20,5 \%$ & $71,4 \%$ \\
Acknowledge minority groups & $13,8 \%$ & $27 \%$ & $59,2 \%$ \\
Acknowledge equality & $9,3 \%$ & $24,3 \%$ & $66,4 \%$ \\
$\begin{array}{l}\text { Accept the variety of sub-cul- } \\
\text { tures and traditions }\end{array}$ & $9,5 \%$ & $21 \%$ & $69,5 \%$ \\
$\begin{array}{l}\text { Develop the spirit of nationalism } \\
\text { based on pluralism }\end{array}$ & $7,8 \%$ & $22,8 \%$ & $69,4 \%$ \\
\hline
\end{tabular}

Source: Analyzed from the primary data

The data findings in this study are in line with the studies conducted by Brown, Tam, \& Aboud (2018). They reviewed various studies which show that the media, in this case, story books, television, and films, were able to reduce the children's level of prejudice against the other ethnic groups. This means that mass media, including social media, can still be considered as a good form of media to use to socialize and internalize pluralism and multiculturalism values. However, the results of their study also showed something different. When anti-pluralism and multiculturalism values are given to children since they are three years old, or to families with lower socio-economic backgrounds, it is quite difficult to change their sense of prejudice toward other ethnic groups. This happens even though they have obtained their information from various media formats such as storybooks, which contain moral messages about the values of pluralism and multiculturalism.

Interestingly, the number of respondents who think that social media often broadcasts news about the cases of conflict or dispute avoidance is the smallest out of the percentage of the other pluralism values 
(63.4 percent). This means that social media tends to present information or news on the conflicts between tribes, religions, and cultures. Such news might be considered more valuable than any other information, while it can actually spark further conflicts or disputes between groups of people. In addition, another interesting fact that exists in the values of multiculturalism is the acknowledgment of minority groups. Quite the number of respondents (13.8 percent) never knew about such news or information on social media. This means that information about the existence and acknowledgment of minority groups is rarely reported or may even be deliberately avoided because it tends to be incompatible with the habits of Indonesian people who are more comfortable in large groups.

The facts revealed by the youths in this study can be considered a projection of the Indonesian condition. The media reflects society and its common behavior, events, and values (Ibrahim \& Akhmad 2014). A study in Chile conducted by Valenzuela, Arriagada, \& Scherman (2012) showed that social media has a significant role in influencing the attitudes and behavior. For instance, social media can move youths to stand up against social problems in their country. This means that if the media tend to inform the public of things that are not conducive, such as reporting conflict, intimidation or violence that occurs between groups, tribes, religions, cultures, and languages, then this will affect the perception and empathy toward the opposing groups, even infuriated the groups who are intimidated.

\section{The assessment of the information quality that supports pluralism and multiculturalism}

Aside from the previous discussion, this section will focus on the assessment of the youths on the quality of the social media information that supports pluralism and multiculturalism values. This needs to be addressed in order to know if the weight of the news content can also determine the quality of the news itself. This study asked the youths to express their opinion about the quality of information that they had accessed on social media, and whether or not it supported pluralism and multiculturalism values.

Table 5.

The Assessment of the Information Quality that Supports Pluralism and Multiculturalism Values

\begin{tabular}{lccc}
\hline \multicolumn{1}{c}{ Values } & No & Less & Sufficient \\
\hline Respect diversity & $3 \%$ & $24 \%$ & $73 \%$ \\
Positively regard plurality & $3,8 \%$ & $26,8 \%$ & $69,4 \%$ \\
Avoid any disputes & $7,3 \%$ & $25 \%$ & $67,7 \%$ \\
Give space for differences & $5,2 \%$ & $26,8 \%$ & $68 \%$ \\
Willing to accept diversity & $5,5 \%$ & $20 \%$ & $74,5 \%$ \\
Acknowledge diversity & $5,2 \%$ & $21,8 \%$ & $73 \%$ \\
Acknowledge minority groups & $8 \%$ & $25,3 \%$ & $66,7 \%$ \\
Acknowledge equality & $5,2 \%$ & $20,8 \%$ & $74 \%$ \\
Accept the variety of sub-cultures & $3,8 \%$ & $21,8 \%$ & $74,2 \%$ \\
and traditions & & & \\
Develop the spirit of nationalism & $5,8 \%$ & $20 \%$ & $74,2 \%$ \\
based on pluralism & & & \\
\hline
\end{tabular}

Source: Analyzed from the primary data

Based on Table 5, it can be seen that the majority of the respondents assessed that the content of the news or information that they accessed supported pluralism and multiculturalism values. The values displayed on social media are about: 1$)$ the willingness to accept differences ( 74.5 percent); 2) the willingness to accept traditions from various sub-cultures and to develop nationalism ( 74.2 percent) and pluralism (74.2);3) acknowledging equality (74 percent) and 4) promoting respect for diversity ( 73 percent). On the contrary, there are several values of pluralism and multiculturalism which, according to the respondents, are not well reported on social media. These include 1) the acknowledgment of minority groups ( 8 percent) and 2 ) avoiding disputes or conflicts between tribes, 
religions, cultures, and languages (7.3 percent). The respondents' answers seemed to be consistent with their assessment of social media's role as an agent of the socialization of pluralism values, in which they thought that social media did not provide too much information about the avoidance of conflict, the disparity between different groups and the acknowledgment of minority groups.

Responding to the study findings, the information bias in the media can be related to the 'failure' of social media's role of providing socialization and quality information. The media is supposed to provide information that helps to avoid conflicts or disputes between different groups and it should also acknowledge minority groups. The results of a study conducted by Manurung (2012) actually showed the opposite. The media tends to broadcast news which stereotypes certain groups, tends to ignore minorities and favors the majority group. The content of the news in the media is a reflection of the imbalanced power relations between the dominant and subordinate groups.

\section{Correlation test}

This section is an attempt to test the correlation between 1) the role of social media as an agent for socializing pluralism and multiculturalism values (Var. X1), 2) the quality of information that supports pluralism and multiculturalism values (Var.X2) and 3) the understanding of the youths referring to pluralism and multiculturalism (Var.Y). Here are the results of the correlation test using Kendall's Tau statistics:

Table 6.

Correlation Test Variable X1, $\mathrm{X} 2$, and $\mathrm{Y}$

\begin{tabular}{|c|c|c|c|c|c|}
\hline \multirow{10}{*}{ 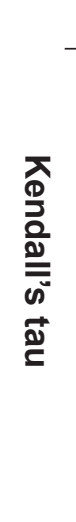 } & & & Var. X1 & Var. X2 & Var. Y \\
\hline & \multirow{3}{*}{$\begin{array}{l}\text { Var. } \\
\text { X1 }\end{array}$} & Correlation Coefficient & 1.00 & $.340^{* *}$ & $.267^{* *}$ \\
\hline & & Significance (1-tailed) & . & .000 & .000 \\
\hline & & $\mathrm{N}$ & 400 & 400 & 400 \\
\hline & Var. & Correlation Coefficient & $.340^{* *}$ & 1.00 & $.169^{* *}$ \\
\hline & \multirow[t]{2}{*}{$\mathrm{X} 2$} & Significance (1-tailed) & .000 & . & .000 \\
\hline & & $\mathrm{N}$ & 400 & 400 & 400 \\
\hline & \multirow{3}{*}{$\begin{array}{c}\text { Var. } \\
\text { Y }\end{array}$} & Correlation Coefficient & $.267^{* *}$ & $.169^{* *}$ & 1.00 \\
\hline & & Significance (1-tailed) & .000 & .000 & . \\
\hline & & $\mathrm{N}$ & 400 & 400 & 400 \\
\hline
\end{tabular}

Based on the statistical test as listed in Table 6 , the results show that the correlation between variables $\mathrm{X} 1$ and $\mathrm{Y}$ is 0.267 , whereas the variables $\mathrm{X} 2$ and $\mathrm{Y}$ are 0.169 with a significance level of 0.01 , or a confidence level of 99 percent. Through the correlation test, it can be concluded that the understanding of the youth's of pluralism and multiculturalism is influenced more or less by the role of social media as an agent of socializing pluralism and multiculturalism values, as well as the quality of the news or information containing the values of pluralism and multiculturalism itself.

However, although the correlation between the variables is said to be quite significant, the strength of the correlation tends to be weak, particularly referring to the correlation between the news that contains pluralism and multiculturalism values and the youth's level of understanding. This finding thus implies the impression that there are still other variables that can influence the youth's level of understanding of pluralism and multiculturalism. If we trace various studies, it is known that the understanding of pluralism-multiculturalism values is constructed and influenced by various factors. Jackson's (2016) study of multicultural education in Hong Kong showed that knowledge or the comprehension of multiculturalism is constructed holistically and integrated throughout the educational process. This means that the construction of multiculturalism understanding through education needs to not only focus on the problem of integrating different cultures, but that it should also increase the positive perception of diversity, including minority groups. Harjatanaya \& Hoon's 
(2018) study of multicultural education in the era of the post-Soeharto regime also shows that, as a formal education institution, schools play the role of being a positive driver or advocate of interethnic interactions and relations among students. The study conducted by Munusamy (2008) in Malaysia, Singapore, and Hawaii showed that there needs to be an agreement between the community members who have intercultural interactions. There also needs to be a balance of acknowledgment, and efficient and effective multicultural insightful policies and laws at the local and global level in order to achieve multiculturalism. In addition, impartial leadership (non-sectarian) is also needed.

\section{Conclusions}

On the findings of this study, and by paying attention to the research problems that have been described in the introductory chapter, we can reach several conclusions. First, even though more than fifty percent of youths in this study claimed to have never heard of the term "pluralism" and "multiculturalism" in their daily lives, their level of comprehension of pluralism and multiculturalism values was good enough, and was influenced by the information that they got through social media.

Secondly, the concern about the increase of radicalism through social media among youths may be temporarily ignored. This is based on the tendency of the respondents' answers in this study, where they generally considered that the information they accessed through social media could be the agents of socializing pluralism and multiculturalism values. This means, however, that social media still has power as an agent of preserving cultural values and guarding the unity of the nation.

Third, the values that are understood more by youths through social media in this study tend to be about pluralism values rather than multiculturalism. The most understood pluralism values are plurality and diversity. This is in line with their assessment of the role and quality of information on social media, which tends to contain pluralism values rather than multiculturalism. Strong evidence for this argument is the respondent's answer that social media rarely informs them of news about conflict avoidance or disputes, and lacks exposure to news or information about the acknowledgment of minority groups. This means that social media tends to report more on conflicts and disputes between groups.

The explanation of the third conclusion resulted in implications for several aspects. First, it is in line with Manuel Castell's idea that information that spreads quickly through social media networks can generate informational capitalism, where information absorbed by youths is highly dependent on those who produce and reproduce the information. The news about social conflict, for instance, from the point of view of informational capitalism, has been constructed in such a way that the information presented has a fairly high selling value. This means that the informational capitalism tends to offer sensational news, including news about the occurrence of conflict, violence etc. On the contrary, the efforts undertaken to spread information that contains values of peace and tolerance tend not to be of high selling value. In other words, if the news or information is in the hands of informational capitalism, then the effort to instill pluralism and multiculturalism values through social media for youths will be distorted when the newsmakers are only concerned with profit and momentary interests. Social media users, as the agents of socializing the pluralism and multiculturalism values, can actually have creative potential by reshaping the construction of meaning-oriented thinking, especially the meaning of nationalism. The creativity that is constructed in pop culture, in this case, social media, can actually be used as an information channel that educates about pluralism and multiculturalism in a fun way by maintaining the social identity of the youths.

The second implication of the third conclusion is that social media still informs more about matters related to pluralism. This is possible because pluralism's understanding is closer to Bhinneka Tunggal Ika, which has been known for a long time in Indonesia. Multiculturalism has a deep meaning, which is more than just an understanding of plurality or diversity. Through multiculturalism, members of a pluralistic society are able to reduce conflict, understand one another's differences and respond to them in a good way, have good intentions to respect all of the different groups in society, coexist peacefully, and support one another in equal positions, even minorities. Social media plays a strategic role in being able to continue to develop the multiculturalism values. The role of social media is 
quite significant in mobilizing youths to be involved in developing pluralism values as well as multiculturalism. This is as shown by Bosch (2017) in his study of the use of social media, in this case, Twitter, as a medium that moves the youth in South Africa to be active, encouraging them to participate in discussions on socio-political issues relevant to contemporary society.

\section{Acknowledgements}

The author would like to thank the Dean of the Faculty of Social and Political Sciences, Airlangga University, for the research funding, and all of the respondents for their participation.

\section{References}

Abadi TW, Sukmawan F, \& Utari DA (2013) Media sosial dan pengembangan hubungan interpersonal di Sidoarjo. Kanal: Jurnal Ilmu Komunikasi 2 (1).

Ayun PQ (2015) Fenomena remaja menggunakan media sosial dalam membentuk identitas. Channel $3(2): 1-16$.

Azra A (2007) Identitas dan Krisis Budaya, Membangun Multikulturalisme Indonesia. http//www. kongresbud.budpar.go.id/58\%20ayyumardi\%20azra.htm.

Barker C (2000) Cultural Studies: Teori dan Praktik, Kreasi Wacana, Yogyakarta.

Bohang FK (2016) Anak Muda Tinggalkan Facebook dan Tweeter, Kenapa?. Kompas.com, https:// tekno.kompas.com.

Bosch T (2017) Twitter activism and youth in South Africa: The cace of \#RhodesMustFall. Information, Communication \& Society, Volume 20:2, 221-232, DOI: 10.1080/1369118X.2016.1162829.

Muhammad AW \& Pribadi KK (2013) Anak muda, radikalisme, dan budaya populer. MAARIF 8 (1).

Harjatanaya TY \& Hoon CY (2018) Politics of multicultural education in Post-Suharto Indonesia: A study of the Chinese minority. Compare: A Journal of Comparative and International Education. DOI: 10.1080/03057925.2018.1493573.

Ibrahim IS \& Akhmad BA (2014) Komunikasi dan Komodifikasi: Mengkaji Media dan Budaya dalam Dinamika Globalisasi. Yayasan Pustaka Obor Indonesia.

Jackson L (2016) Learning about diversity in Hong Kong: Multicultularism in liberal studies textbooks. Asia-Pacific Edu Res (2017) 26 (1-2):21-29. DOI 10.1007/s40299-016-0323-0.

Logli C (2015) Bhineka Tunggal Ika (Unity in Diversity): Nationalism, Ethnicity, and Religion in Indonesian Higher Education. A Dissertation Submitted to The Graduate Divison of The University of Hawai'i At Manoa UMI microform 3717195. Published by ProQuest LLC.

Maftuh B (2008) Internalisasi nilai-nilai Pancasila dan nasionalisme melalui pendidikan kewarganegaraan. Educationist II (2).

Manurung H (2012) The Impact of Global Culture toward Local Wisdom: A Study on Multiculturalism \& Mass Media. IJAS Rome. https://ssrn.com/abstract=3132736.

Misrawi Z (2012) Kesadaran multikultural dan deradikalisasi pendidikan Islam: Pengalaman Bhinneka Tunggal Ika dan Qabul Al-akhar. Jurnal Pendidikan Islam 2.

Munusamy VP (2008) Decoding The Meaning of Multiculturalism: An International Study of Malaysia, Singapore and Hawai'i. A dissertaton Submitted to The Graduate Division of The Hawai'i. UMI microform 3347667. Published by ProQuest LLC.

Nurudin (2013) Basis nilai-nilai perdamaian: Sebuah antitesis radikalisme agama di kalangan mahasiswa. Harmoni 12 (3).

Parsley A (2000) A Comparative Analysis of Multicultural Education in Australia, Singapore, and the United States. A Dissertation Submitted to The Faculty of The Graduate School in Candidacy 
for The Degree of Doctor of Philosophy, Department of Leadership Foundations and Counseling Psychology. Loyola University Chicago, Illinois, UMI Microform No.9955405, copyright by Bell \& Howell Information and Learning Company.

Parikesit AA (2013) Peran Media Sosial dalam Pendidikan. https://m.detik.com/inet/ cyberlife/d-2233962/peran-media-sosial-dalam pendidikan, Kolom Telematika, Selasa 30 April 2013 12.56 WIB.

Rahman S (2014) Islam dan pluralisme. Fikrah 2 (1).

Sugihartati R (2014) Perkembangan Masyarakat Informasi dan Teori Sosial Kontemporer, Kencana Prenadamedia Group, Indonesia.

Suparlan S (2014) Menuju masyarakat Indonesia yang multikultural. Antropologi Indonesia 0 (69).

Sutaryo (2007) Sosiologi Komunikasi. Universitas Terbuka Departemen Pendidikan Nasional, Indonesia.

Syaifuddin AF (2006) Membumikan multikulturalisme di Indonesia. Jurnal Antropologi Sosial Budaya ETNOVISI II (1).

Winataputra US \& Saripudin S (2008) Multikulturalisme-Bhinneka Tunggal Ika dalam perspektif pendidikan kewarganegeraan sebagai wahana pembangunan karakter bangsa Indonesia. Jurnal Pendidikan dan Kebudayaan 075.

Valenzuela S, Arriagada A, \& Scherman A (2012) The social media basis of youth protest behaviour: The case of Chile. Journal of Communication 62 (2):299-314. https://doi.org/10.1111/j.14602466.2012.01635.x. 